\title{
Effects of STEM Education Seminars on Teachers in the Schools of North Cyprus
}

\author{
Gülyüz Debeş ${ }^{1 *}$ \\ ${ }^{1}$ Near East University, Lefkosa, CYPRUS
}

Received 11 May $2018 \cdot$ Revised 22 July 2018 - Accepted 23 July 2018

\begin{abstract}
In this study, Seminars were envisaged on the importance of stem education at secondary schools. Basicly these seminars were about to introduce STEM education to the teachers. Pre-test and post-tests were applied in the study. By this way, it was aimed to measure the effectiveness of the seminars on especially maths and technology related courses of teachers. Three scales are used to test the effectiveness of the seminars. As for the results it was found that teachers were positively effected by the mathematical self literacy but had no difference in their mathematical thinking ability and in terms of their technological use.
\end{abstract}

Keywords: STEM education, seminars, mixed methods, technological level of use

\section{INTRODUCTION}

In our changing world, accessing information, ways of research, questioning, critical thinking, being sensitive to social problems, having democratic values and the places where free, independent, respectful people grown up are called schools (Şişman, Güleş, \& Dönmez, 2010; Widdowson et al., 2014). Research that investigates the impact of using emerging technologies to explore real-world problems using inquiry as the central pedagogical approach will become increasingly important. This impact might include gains in students' scientific knowledge, but it might also positively influence students' interest and dispositions with respect to STEM-related career paths (Crippen \& Archambault, 2012). Many states are still seeing education as a key point for their sustainable future and share the responsibility to educate their citizens in their schools in order to have future strong labour force in their counties. The jobs requiring skills related with science, technology and engineering are 26 percent higher than jobs in the non-STEM fields.

Modern schools are aware of the fact that they have to modernize their learning environment in line with Stem. The proponents of STEM education believe that by increasing math and science requirements in schools, along with infusing technology and engineering concepts, students will perform better and be better prepared for advanced education or jobs in STEM related fields. (Brown et al., 2011) Not only the decision making of school administrators but also the learning environment is key for success in education. Therefore developmental effort is needed at the creation of learning environments that will engage learners' understanding and provide learners with a setting in which they can construct more powerful system concepts and insights. The importance of the social environment in learning stems from the work of theorists who frame learning as a social act: interaction between and among individuals plays a critical role in cognitive development (Vygotsky, 1978) STEM Learning Environments are the new contemporary places for learning. Learning in these environments contributes to the development of higher level cognitive skills and increases the responsibility for the students' own learning. Students start constructing knowledge that is new to themselves and develop skills that will bring them from the level of novice to expert learners (Dreyfus, 2004). Vennix, den Brok, and Taconis (2018) notes how outreach learning environments indeed created opportunities to increase students' motivation in STEM and attitude towards STEM.

Chen and Stroup (1993) simulated learning environments as crucial to pursue learning research in the context of real-world settings. Mostly the advantages of using computer-based simulations to advance system thinking need to be fully investigated and employed in schools. Johassen (1999) underlines that Computer - Supported Intentional Learning Environments (CSILEs) are helpful to the students to produce knowledge databases that can

(C) 2018 by the authors; licensee Modestum Ltd., UK. This article is an open access article distributed under the terms and conditions of the Creative Commons Attribution License (http://creativecommons.org/licenses/by/4.0/). \dgulyuz@yahoo.com (*Correspondence) 


\section{Contribution of this paper to the literature}

- STEM learning environments contributes to the development of higher level cognitive skills and increases the responsibility for the students' own learning.

- Teachers need to benefit from professional-development opportunities that focus on how to use inquirybased instruction to create, and implement cyberlearning materials.

- Teachers were positively effected by the mathematical self literacy but had no difference in their mathematical thinking ability and in terms of their technological use.

be; objectified, represented in an overt form or that can be evaluated and examined to overcome inadequacies. There is no reason to believe that real-world learning environments are any less rich, and actually research and development should focus on these changing learning environment. Even before the students, the main reformation is to be done starting from the teachers because they are the ones shaping the educational process. This study is focusing on the educational seminars held towards teachers at different schools of North Cyprus working at secondary educationary level. Seminars were held about STEM education and 3 different expert academicians involved.

Many countries today are reformulating their curriculum and educational agenda in line with the STEM education. Science, Technology, Engineering, and Mathematics (STEM) education has been a part of the culture of education in the United States since the National Science Foundation (NSF) coined the term in the early 2000s. There are similar ways in which it resembles to systems approach the way it is implemented. Educational reforms started to dominate STEM integration through mandated testing (Myers \& Dyer, 2004). In the USA, the federal government spends nearly $\$ 3$ billion on STEM education programs annually. Private funding also supports STEM education with an additional US\$1 billion each year. Twenty-first century skills is a framework of soft skills consisting of multiple cognitive constructs interacting to produce outcomes. The authors further group 21st century skills into a larger grouping based on overarching cognitive relationships. Each of these skills is important for students to be successful in an information-based economy such as those found in the United States, China, and other counties. The metaskills in the 21st century skills framework consist of critical thinking, production, creativity, and problem solving (Lamb, Vallett, \& Annetta, 2014). The ever-increasing interests and research are also evidenced in the active development of numerous professional organizations and conferences related to STEM education. Despite the doubts have arisen among students, including at-risk and low achievers, have difficulty understanding STEM concepts when taught in standalone courses, it can be seen that when the teachers are trained in line with Stem, the system Works. (Boaler, 1998; Woodward \& Montague, 2002). When the benefits of STEM is analysed it can be easily seen that the education methodology of Stem is going to be widespread for the next decades.

Zemelman, Daniels, and Hyde (2005) list ten best practices for teaching math and science: (1) use manipulatives and hands-on learning; (2) cooperative learning; (3) discussion and inquiry; (4) questioning and conjectures; (5) use justification of thinking; (6) writing for reflection and problem solving; (7) use a problem solving approach; (8) integrate technology; (9) teacher as a facilitator; (10) use assessment as a part of instruction.

Together with the concepts above, the survival, continuity, efficiency and productivity of a Stem based school leads to a success. That brings together the fulfillment of adopting contemporary school management approach that is sensitive to respond to the needs of the members of the school and to Stem oriented targets. School administrators should closely follow the latest developments in management and should implement the concepts of STEM Education.

For a long time, North Cyprus schools used a semi-open systems approach both on the macro level management of the Ministry and also micro management of the schools by the administrators. Gokel \& Dagli, (2015) historically shows the practice of systems approach in the educational model formed in North Cyprus that even had influences from the Ottoman Period. In Northern part of the Cyprus, schools, their management, functionality, internal affairs of education and curriculum arrangements, measurement and evaluation, construction of school buildings, law enforcements, supervision, budgeting and everything about the teachers are all under the responsibility of Ministry of National Education and Culture (Açıkalın, 2014). Systems Approach was widely used in managing the schools and the whole structure looks like a half open half closed system. The theoretical potential of general system theory for science education was significant. For Chen and Stroup (1993) one thing to identify the central tenets of "system thinking," was to characterize and advance a learners' understanding of system ideas. Shift from systems approach to a Stem based educational system can only be possible through trainings of teachers in North Cyprus.

The training of STEM (Science, Technology, Engineering and Mathematics) of these professionals require the development of well-qualified experts in their subject fields who are able to respond to the constant demands of the workforce both in industry or academia. 


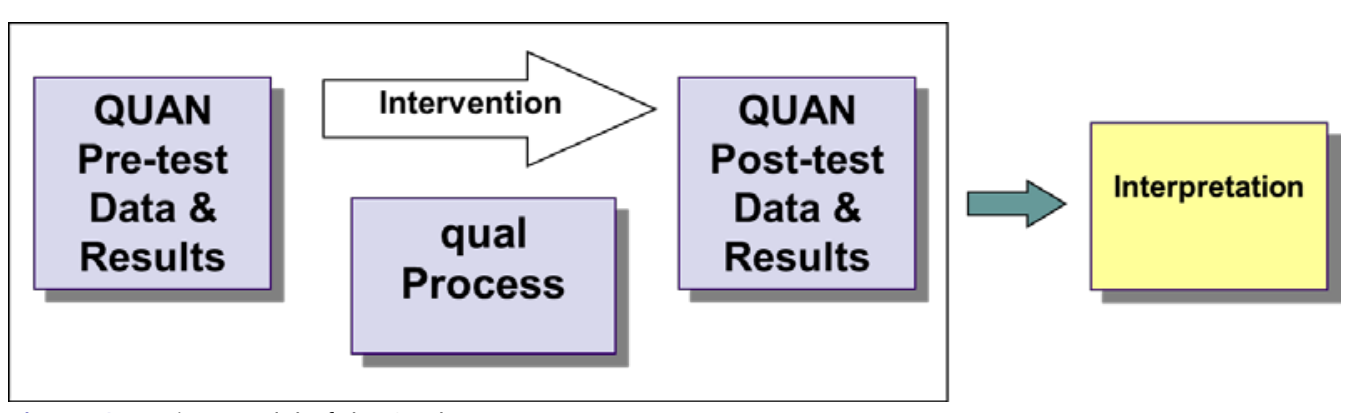

Figure 1. Design Model of the Study

STEM education is quite new concept for newly developing country of North Cyprus and this study aims to show the importance of seminars taken to have whether there was an impact on the teaching of maths, science, engineering and technology courses carried out by teachers.

\section{METHOD}

Mixed Method research is used in the study. Mixed method embedded design with a triangulation was applied in the study. The Embedded Design is a mixed methods design in which one data set provides a supportive, secondary role in a study based primarily on the other data type (Creswell, et al., 2003). This design is particularly useful when a researcher needs to embed a qualitative component within a quantitative design, as in the case of an experimental or correlational design.

In order to determine the effects of seminars, a single group pre-test post-test model was applied.

As for the qualitative aspect of the study, the seminars were given with the views from three experts in the field, one expert in mathematics department, and one expert academic in educational technology and one expert in science education department. Seminars lasted 4 days with 5 hours each day under having 4 topics of Science, Technology, Engineering and Mathematics.

Quantitative part included, three scales were used to test the effectiveness of the seminars. Three different scales were applied to teachers employed at 4 different secondary schools in North Cyprus.

The "Mathematical Thinking Scale" developed by Ersoy and Başer (2013) was used. This scale was developed in accordance with the 5-point Likert type. The researchers calculated the KMO value of the scale as .759 and the Barlett sphericity test was found to be significant. The reliability of the scale was calculated to be .78 . The scale consists of 4 sub-dimensions and 25 items in total. In the scope of the research, the reliability value of the scale was calculated as .84 .

The "Mathematics literacy self-efficacy scale" developed by Özgen and Bindak (2008) was used. This scale was developed in accordance with the 5-point Likert type. The researchers found the KMO value of the scale to be .92 . The Barlett test of the scale was found to be significant. The reliability of the scale was calculated to be .92 . The scale consists of one dimension and 25 items. The reliability value of the scale within the scope of the research was calculated as .90 .

The reliability of the scales used to collect quantitative data were examined separately and the value of all was found to be higher than .70. This indicates that these scales can be used in research.

Technology Level of Use Scale developed by Isleem (2006) was used. This scale was developed in accordance with the five scale Likert format. The reliability value of the scale was calculated as 0.92 , while for the sub-scale included in the scale. The scale consists of 13 items in total. Sixty participants were involved in the sampling.

\section{FINDINGS}

Demographical statistics of participants were given in the first part of the findings and this part is followed up by the inferencial statistical data that is collected after the scale results.

Table 1 shows the gender distribution of the participants as of the (67\%) participants are male and eleven of them $(33 \%)$ were female. 
Table 1. Gender distribution of the participants

\begin{tabular}{llll}
\hline & & F & $\%$ \\
\hline \multirow{3}{*}{ Gender } & Women & 40 & 67 \\
\cline { 2 - 5 } & Male & 20 & 33 \\
\cline { 2 - 5 } & Total & 60 & 100 \\
\hline
\end{tabular}

Table 2. Marital Status of the participants

\begin{tabular}{llll}
\hline & & $\mathbf{f}$ & $\%$ \\
\hline \multirow{3}{*}{ Marital Status } & Married & 50 & 84.4 \\
\cline { 2 - 5 } & Single & 10 & 16.6 \\
\cline { 2 - 5 } & Total & 60 & 100 \\
\hline
\end{tabular}

Table 3. Statistics on mathematical literacy self-efficacy, mathematical thinking, and technology level of use scale

\begin{tabular}{lllcccc}
\hline Scale & Test & $\mathbf{N}$ & $\mathbf{X}$ & $\mathbf{S D}$ & Minimum & Maximum \\
\hline \multirow{2}{*}{ Mathematical Literacy Self-Efficacy Scale. } & Pre-test & 60 & 82.20 & 8.34 & 82 & 113 \\
\cline { 2 - 7 } Mathematical Thinking Scale & Post-test & 60 & 96.74 & 9.76 & 80 & 124 \\
\hline \multirow{2}{*}{ Technology Level of Use } & Pre-test & 60 & 81.48 & 6.66 & 88 & 118 \\
\cline { 2 - 7 } & Post-test & 60 & 82.65 & 8.72 & 95 & 125 \\
\hline
\end{tabular}

Table 4. T-test results test results on the scale of Mathematical Literacy Self-Efficacy

\begin{tabular}{|c|c|c|c|c|c|c|c|}
\hline & \multicolumn{3}{|c|}{ Pre - test } & \multicolumn{2}{|c|}{ Post test } & \multirow[b]{2}{*}{$\mathbf{t}$} & \multirow[b]{2}{*}{$\mathbf{P}$} \\
\hline & $\mathbf{N}$ & $\overline{\mathrm{X}}$ & SD & $\overline{\mathrm{X}}$ & SD & & \\
\hline Mathematical Literacy Self-Efficacy Scale. & 60 & 82.20 & 8.34 & 96.74 & 9.67 & 2.120 & $.011^{\star}$ \\
\hline
\end{tabular}

Table 5. T-test results of the Mathematical Thinking Scale

\begin{tabular}{lccccccc}
\hline & \multicolumn{1}{c}{ Pre - test } & Post test \\
\hline & $\mathbf{N}$ & $\overline{\mathrm{X}}$ & SD & $\overline{\mathrm{X}}$ & $\mathbf{S D}$ & $\mathbf{t}$ & $\mathbf{P}$ \\
\hline Mathematical Thinking Scale & 60 & 81.48 & 6.66 & 82.65 & 8.72 & .345 & .834 \\
\hline
\end{tabular}

Table 6. T-test results of the Technology Level of Use Scale

\begin{tabular}{lccccccc}
\hline & \multicolumn{1}{c}{ Pre - test } & Post test \\
\hline & $\mathbf{N}$ & $\overline{\mathrm{X}}$ & SD & $\overline{\mathrm{X}}$ & $\mathbf{S D}$ & $\mathbf{t}$ & $\mathbf{P}$ \\
\hline Technology Level of Use Scale & 60 & 160.28 & 23.76 & 166.10 & 26.46 & .512 & .713 \\
\hline
\end{tabular}

Table 2 shows that Fifty of the (84.4\%) of the individuals answered were married and ten of them $(16.6 \%)$ were single.

Table 3 shows scores for the scale results as following; mathematical literacy self-efficacy scale pre-test $(\overline{\mathrm{X}}=$ 82.20) and post-test $(\overline{\mathrm{X}}=96.74)$; The Mathematical Thinking Scale pre-test $(\overline{\mathrm{X}}=81.48)$ and the post-test $(\overline{\mathrm{X}}=82.65)$ and the Technology Level of Use scale pre-test $(\overline{\mathrm{X}}=160.28)$ and post-test $(\overline{\mathrm{X}}=166.10)$.

The results obtained from the t-test analysis for the dependent groups, which were made in order to determine the effects of the STEM seminars on the effects of the mathematics literacy are given in Table 4.

When Table 4 is examined, there is a significant difference statistically between the mathematical literacy selfefficacy scale pre-test and post-test points arithmetic calculations of the teachers and who are in mathematics teaching $=2.120, .011=\mathrm{p}<.05$ ]. The results obtained from the t-test analysis for the dependent groups in order to reveal the effects of the STEM seminars on the mathematical thinking ability of the teachers are given in the Table 5.

According to Table 5, there is no statistically significance found between pre-test post-test arithmetic average of Mathematical Thinking Scale results. This meaning that the technological use ability of the teachers are not effected significantly from the Stem Seminars. (.834, $\mathrm{p}>.05)$.

According to Table 6, there is no statistically significance found between pre-test post-test arithmetic average of Technology Level of Use scale. $(.713, \mathrm{p}>0.5)$ This meaning that the technological use ability of the teachers are not effected significantly from the Stem Seminars. 


\section{DISCUSSION}

In this study, the effects of STEM seminars on math literacy self-efficacy, mathematical thinking skills and technology level of use are investigated. STEM education has the objective to equip students with the knowledge, skills, attitudes and competencies that will enable them to cope with the uncertainty of the knowledge society (Huet, 2017). As a result of the study, it was found that STEM seminars changed the mathematics literacy selfefficacy of the teachers positively. According to this result, it can be said that STEM seminars or in house education facilities have a positive effect on mathematical literacy. STEM education improves mathematics and science literacy in many studies (Weber, Fox, Levings, \& Bouwma-Gearhart, 2013). Figliano (2007) undelined STEM education as a contributor to the development of science and mathematics literacy, and even to the development of STEM literacy itself.

Some studies show that STEM education also improves the technological literacy and the level of use (Wang, Moore, Roehring, \& Park, 2011). However no significant relationship was found after having the Stem seminars average scores of pre and post tests.

In the study, the effects of STEM applications on mathematical thinking of teachers have been also examined. As a result of the study, it was concluded that STEM applications did not positively affect the Mathematical Thinking of teachers participated. STEM seminars seem to have a positive impact on the strategic thinking and questioning dimension. Furner (2017) states that math teaching should cover councelling methods to get rid of the math anxiety and seminars are beneficial in that way. Teachers of mathematics, after training or seminars, need to take on the role of counselors to address the math anxious students they have in their classrooms. However, this study findings show that STEM seminars have no significant positive effect on mathematical thinking of the participant teachers. This result can be discussed through the cultural factors and resistance to the change of the North Cyprus teachers. Since Finlayson 2014 asserts that the type of authority the teacher uses, an emphasis on right answers and fear of getting wrong answers, requirements that the student respond with an answer sooner than he or she might be ready, and exposure to the rest of the class and their potential condemnation of a student who responds poorly. Therefore classroom environment can further be investiged in that case.

Kim and Choi (2012) researched the effect of the science-based STEAM program on problem solving skills. As a result of the research, it is found that the science-based STEAM program had a positive effect on students' problem-solving skills. Krishnamurthi, Ballard and Noam (2014) studied the effects of post-school STEM programs. As a result of the researches, they found that STEM programs contributed positively to the development of problem solving skills. Wang (2012) stated that the purpose of the STEM integration courses was to improve problemsolving skills. However, when the literature is examined, it is seen that STEM seminars also have positive effects on the attitude, interest, academic success, scientific process skills and motivation of the individuals (Chittum, Jones, Akalin \& Schram, 2017; Olivarez, 2012; Park \& Yoo, 2013).These results show that STEM seminars have a positive effect also on different variables.

\section{CONCLUSION}

In the scope of the research, the effect of STEM seminars on teachers technology level of use has been examined. As a result of the study, it is concluded that STEM seminars had no influence on technology level of use of teachers. The technological device use or intention towards technological material is not leveled up after the given seminars, the reason behind that might be the insufficent budget of the schools to have the tools or the teachers do not see it as a necessity to carry out the lectures with new materials. Wang, Moore, Roehring and Park (2011) stated that teachers are lacking digital technological resources and a good STEM program for their use. Similarly, Wang (2012) emphasizes that a good program for STEM education is a must but sadly it is lacking. This is a similar situation for North Cyprus schools and seminars aiming to raise up the consciousness about the issue should continue. Thibaut et al. (2018) states that while teachers and educators can use the five principles to develop curriculum materials for integrated STEM in a fine-grained manner, educational researchers can employ them to analyse instructional practices in more detailed and specific ways. These key principles to be shared for North Cyprus schools and for all the schools are: integration of STEM content, problem-centered learning, inquiry-based learning, design-based learning and cooperative learning. Therefore one of the benefits of this study is to underline the seminars' importance for setting up these principles in a developing country. Lastly the results of the study shows that teachers were positively effected by the mathematical self literacy but had no difference in their mathematical thinking ability and in terms of their technological use. Especially for the case of technology teachers' ineffective seminar training has to be questioned because the literature tells us technology education of teachers as a must for Stem mentality. Crippen and Archambault (2012) states that in-service and pre-service teachers need to benefit from university-level coursework and professional-development opportunities that focus on how to use inquirybased instruction to create, scaffold, and implement cyberlearning materials. 


\section{REFERENCES}

Açıkalın, A. (2014). Eğitimde İnsan Kaynağının Yönetimi. S. Turan İçinde, Ĕ̆itim Yönetimi Teori, Araştırma ve Uygulama. Ankara: Pegem.

Boaler, J. (2000). Exploring situated insights into research and learning. Journal for research in mathematics education, 113-119. https:// doi.org/10.2307/749822

Brown, R., Brown, J., Reardon, K., \& Merrill, C. (2011). Understanding STEM: current perceptions. Technology and Engineering Teacher, 70(6), 5.

Chen, D., \& Stroup, W. (1993). General system theory: Toward a conceptual framework for science and technology education for all. Journal of Science Education and Technology, 2(3), 447-459. https://doi.org/10.1007/BF00694427

Chittum, J. R., Jones, B. D., Akalin, S., \& Schram, A. B. (2017). The effects of an afterschool STEM program on students' motivation and engagement. International Journal of STEM Education, 4(11), 2-16. https:/ / doi.org/10.1186/s40594-017-0065-4

Creswell, J. W., Plano Clark, V. L., Gutmann, M., \& Hanson, W. (2003). Advanced mixed methods research designs. In A. Tashakkori \& C. Teddlie (Eds.), Handbook of mixed methods in social and behavioral research (pp. 209240). Thousand Oaks, CA: Sage

Crippen, K. J., \& Archambault, L. (2012). Scaffolded inquiry-based instruction with technology: A signature pedagogy for STEM education. Computers in the Schools, 29(1-2), 157-173. https:/ / doi.org/10.1080/07380569.2012.658733

Dreyfus, S. E. (2004). The five-stage model of adult skill acquisition. Bulletin of science, technology $\mathcal{E}$ society, 24(3), 177-181. https:/ /10.1177/0270467604264992

Ersoy, E., \& Başer, N. E. (2013). Matematiksel düşünme ölçeğinin geliştirilmesi. Kastamonu Üniversitesi Kastamonu Ĕ̈itim Dergisi, 21(4), 1471-1486.

Figliano, F. (2007). Strategies for integrating STEM content: A pilot case study. (Unpublished masters dissertation). Virginia Polytechnic Institute and State University, Virginia.

Finlayson, M. (2014). Addressing math anxiety in the classroom. Improving Schools, 17(1), 99-115. https:/ / doi.org/10.1177/1365480214521457

Furner, J. M. (2017). Teachers and Counselors: Building Math Confidence in Schools. European Jourrnal of STEM Education, 2(2), 3. https:// doi.org/10.20897/ ejsteme.201703

Gökel, Ö., \& Dağlı, G. (2015). Osmanlı'dan Günümüze Kıbrıs Türk Eğitim Sisteminin Geçirmiş Olduğu Evreler. Journal of International Social Research, 8(37). https:/ / doi.org/10.17719/jisr.20153710641

Huet, I. (2017). Research-based education as a model to change the teaching and learning environment in STEM disciplines. European Journal of Engineering Education, 1-16. https:/ / doi.org/10.1080/03043797.2017.1415299

Isleem, M.B. (2003). Relationships of selected factors and the level of computer use for instructional purposes by technology education teachers in Ohio public schools: A statewide survey (Unpublished PhD thesis), The Ohio State University.

Jonassen, D. H. (1999). Designing constructivist learning environments. Instructional design theories and models: A new paradigm of instructional theory, 2, 215-239.

Karakuş, M. (2014). Eğitim Yönetiminde Değerler. S. Turan İçinde, Ĕ̆itim Yönetimi, Teori, Araştırma ve Uygulama. Ankara: Pegem.

Kim, G. S., \& Choi, S. Y. (2012). The effect of creative problem solving ability and scientific attitude through the science based STEAM program in the elementary gifted students. Journal of Korean Elementary Science Education, 31(2), 216-226.

Krishnamurthi, A., Ballard, M., \& Noam, G. G. (2014). Examining the Impact of Afterschool STEM Programs. Afterschool Alliance. Retrieved on 12/10/2017 from http://alabamaacn.org/wpcontent/uploads/2014/11/Examining-the-Impact-of-AfterschoolPrograms-STEM-Implementation.pdf/

Lamb, R. L., Vallett, D. B., \& Annetta, L. (2014). Development of a short-form measure of science and technology self-efficacy using Rasch analysis. Journal of Science Education and Technology, 23, 641-657. https:/ / doi.org/10.1007/s10956-014-9491-y

Myers, B. E., \& Dyer, J. E. (2004). Agriculture teacher education programs: A synthesis of the literature. Journal of Agricultural Education, 45(3), 44-52. https:/ / doi.org/10.5032/jae.2004.03044

Olivarez, N. (2012). The Impact of a STEM program on academic achievement of eighth grade students in a south texas middle school (Unpublished doctoral dissertation). Texas A \& M University, Texas. 
Özgen, K., \& Bindak, R. (2008). Matematik okuryazarlığı öz-yeterlik ölçeğinin geliştirilmesi. Kastamonu Ĕ̆itim Dergisi, 16(2), 517-528.

Özmen, F., \& Yörük, S. (2005). İnsan Kaynakları Yönetimi Çerçevesinde, Okul Yöneticilerinin Karar Verme Sürecindeki Etkiliklerine İlişkin Ölçek Geliştirilmesi, Journal of Social Science, 179.

Park, S. J., \& Yoo, P. K. (2013). The Effects of the learning motive, interst and science process skills using the "light" unit in science-based STEAM. Elementary Science Eucation, 32(3), 225-238.

Şişman, M., Güleş, H., \& Dönmez, A. (2010). Demokratik Bir Okul Kültürü İçin Yeterlilikler Çerçevesi. Uşak Üniversitesi Sosyal Bilimler Dergisi, 3(1), 167-182.

Thibaut, L., Ceuppens, S., De Loof, H., De Meester, J., Goovaerts, L., Struyf, A., \& Depaepe, F. (2018). Integrated STEM education: A systematic review of instructional practices in secondary education. European Journal of STEM Education, 3(1), 02. https:// doi.org/10.20897/ ejsteme/83659

Vennix, J., den Brok, P., \& Taconis, R. (2018). Do outreach activities in secondary STEM education motivate students and improve their attitudes towards STEM? International Journal of Science Education, 1-21. https:// doi.org/10.1080/09500693.2018.1473659

Vygotsky, L. S. (1978). Mind in society, the development of higher psychological processes. Cambridge, MA: Harvard University Press.

Wang, H. H. (2012). A new era of science education: science teachers' perceptions and classroom practices of science, technology, engineering, and mathematics (STEM) integration (Unpublished doctoral dissertation). The University of Minnesota, Minnesota.

Wang, H. H., Moore, T. J., Roehrig, G. H., \& Park, M. S. (2011). STEM integration: Teacher perceptions and practice. Journal of Pre-College Engineering Education Research (J-PEER), 1(2), 2.

Weber, E., Fox, S., Levings, S. B., \& Bouwma-Gearhart, J. (2013). Teachers' conceptualizations of integrated STEM. Academic Exchange Quarterly, 17(3), 1-9.

Widdowson, D. A., Dixon, R. S., Peterson, E. R., Rubie-Davies, C. M., \& Irving, S. E. (2015). Why go to school? Student, parent and teacher beliefs about the purposes of schooling. Asia Pacific Journal of Education, 35(4), 471-484. https:/ / doi.org/10.1080/02188791.2013.876973

Woodward, J., \& Montague, M. (2002). Meeting the challenge of mathematics reform for students with LD. The Journal of Special Education, 36(2), 89-101. https:/ / doi.org/10.1177/00224669020360020401

Zemelman, S., Daniels, H., \& Hyde, A. (2005). Best practice: Today's standards for teaching and learning in America's schools. Education Review//Reseñas Educativas.

\section{http://www.ejmste.com}

